\title{
Pemenuhan Gizi Seimbang Bagi Lansia Di Pulau Gili Iyang Kecamatan Dungkek
}

\author{
Iva Gamar Dian Pratiwi' ${ }^{1)}$, Zakiyah Yasin'2), Emdat Suprayitno ${ }^{3)}$ \\ ${ }^{1,2,3)}$ Fakultas Ilmu Kesehatan, Universitas Wiraraja \\ Email ; $\underline{\text { kura_15587@yahoo.com }}{ }^{1)}$, kebidanan.fik@gmail.com ${ }^{2)}$, $\underline{\text { emdats@yahoo.com }}^{3)}$
}

\begin{abstract}
Abstrak
Giliiyang merupakan sebuah pulau yang termasuk dalam wilayah Kecamatan Dungkek Kabupaten Sumenep. Pulau Giliiyang memiliki dua desa yaitu desa Banra'as dan Bancamara. Menurut data dari Pemerintah Kabupaten Sumenep, jumlah lansia di Pulau Giliiyang yang berusia 60 tahun ke atas mencapai 1.285 orang dan 100 tahun ke atas mencapai 157 orang. Sesuai dari hasil pengkajian hampir 90\% lebih lansia di pulau Giliiyang memiliki tingkat pendidikan rendah sehingga salah satu nya berdampak pada pengetahuan yang rendah pula tentang pemenuhan gizi seimbang. Salah satu kegiatan yang dapat dilakukan oleh kelompok untuk membantu masyarakat menghadapi salah satu hambatan tersebut adalah dengan mengadakan kegiatan penyuluhan sekaligus demonstrasi tentang pemenuhan gizi yang seimbang bagi lansia, sehingga diharapkan dengan adanya penyuluhan tersebut pengetahuan lansia meningkat dan bisa merubah pola hidup mereka menjadi lebih baik khususnya yang berkaitan dengan gizi seimbang. Masyarakat sangat antusias dengan kegiatan penyuluhan kepada masyarakat.
\end{abstract}

Kata Kunci: Pemenuhan gizi seimbang, lansia

\section{Pendahuluan}

Giliiyang merupakan sebuah pulau yang termasuk dalam wilayah Kecamatan Dungkek Kabupaten Sumenep. Pulau Giliiyang memiliki dua desa yaitu desa Banra'as dan Bancamara, untuk bisa sampai ke pulau giliiyang harus menggunakan sarana transportasi kapal perahu dari pelabuhan dengan waktu tempuh sekitar 1- 1.5 jam tergantung kondisi cuaca pada saat itu.(Pemkab Sumenep,2017)

Jumlah penduduk Giliiyang mencapai 9.185 jiwa dan 3.867 KK (pemkab Sumenep,2017). Sesuai dengan hasil pengkajian didapatkan beberapa hambatan atau permasalahan yang saat ini di hadapi oleh masyarakat di Pulau Giliiyang, diantaranya adalah:

- Keterbatasan sarana listrik, yang hanya hidup di malam hari

- Rendahnya tingkat pengetahuan lansia tentang pemenuhan gizi seimbang

- Keterbatasan sarana penunjang pariwisata

- Keterbatasan sarana transportasi menuju daratan.

- Sanitasi dan PHBS yang kurang.

Menurut data dari Pemerintah Kabupaten Sumenep (2017), jumlah lansia di Pulau Giliiyang yang berusia 60 tahun ke atas mencapai 1.285 orang dan 100 tahun ke atas mencapai 157 orang. Sesuai dari hasil pengkajian hampir $90 \%$ lebih lansia di pulau Giliiyang memiliki tingkat pendidikan rendah sehingga salah satu nya berdampak pada pengetahuan yang rendah pula tentang pemenuhan gizi seimbang.

Masa tua identik dengan menurunnya kesehatan, semangat, dan performa tubuh. Para manula sering diidentikkan dengan produktifitas dan aktivitas yang semakin menurun. Sebuah penelitian menemukan jika kemampuan metabolisme lansia menurun hingga $15 \%$ hingga $20 \%$. Hal tersebut menunjukkan bahwa kemampuan organ pencernaan untuk mencerna makanan mengalami penurunan, maka dianjurkan bagi para lansia untuk mengonsumsi karbohidrat dan serat yang cukup di masa tua. 
Salah satu kegiatan yang dapat dilakukan oleh kelompok untuk membantu masyarakat menghadapi salah satu hambatan tersebut adalah dengan mengadakan kegiatan penyuluhan sekaligus demonstrasi tentang pemenuhan gizi yang seimbang bagi lansia, sehingga diharapkan dengan adanya penyuluhan tersebut pengetahuan lansia meningkat dan bisa merubah pola hidup mereka menjadi lebih baik khususnya yang berkaitan dengan gizi seimbang.

\section{Permasalahan Mitra/ Kelompok sasaran}

Kelompok bersama dengan masyarakat bermusyawarah untuk sama sama menentukan prioritas permasalahan. Prioritas permasalahan tersebut disesuaikan dengan disiplin ilmu yang dimiliki oleh kelompok, maka dari beberapa permasalahan tersebut kelompok dan masyarakat sepakat untuk lebih di fokuskan pada mengatasi kurangnya pengetahuan lansia tentang gizi seimbang. Kelompok mencoba menawarkan beberapa tekhnik untuk membantu menyelesaikan permasalahan tersebut di antaranya berupa penyuluhan dan demonstrasi langsung kepada masyarakat Pulau Gili iyang.

\section{Tujuan atau Target Luaran}

- Setelah dilakukan penyuluhan pengetahuan lansia bertambah tentang nutrisi seimbang.

- Pola hidup para lansia berubah lebih baik khususnya pada nutrisi

- Kebutuhan nutrisi lansia bertambah

- Para Lansia dapat menentukan menu makanan seimbang

\section{Manfaat}

a. Bagi Masyarakat

Masyarakat dapat mengetahui dengan jelas bagaimana nutrisi yang baik benar khusus nya bagi lansia, sehingga masyarakat bisa mulai merubah pola hidup yang kurang baik

b. Bagi Pelaksana

Tim pelaksana PKM bisa lebih memahami karakteristik pola hidup yang berkaitan nutrisi khususnya bagi lansia di beberapa daerah yang berbeda.

\section{Metode Pelaksanaan}

Usia lanjut dikatakan sebagai tahap akhir perkembangan pada daur kehidupan manusia. Dalam kehidupan ini manusia mengalami penuaan. Batasan usia lansia menurut Depkes RI (2009) adalah usia 46-65 tahun. Seseorang yang sudah memasuki masa lansia banyak mengalami masalah nutrisi maupun perubahan- perubahan fisiknya. Perubahan perubahan fisik ialah jumlah sel berkurang dan cairan tubuh menurun. Berbagai upaya yang dapat dilakukan untuk mengatasi masalah nutrisi pada lansia antara lain monitoring $\mathrm{BB}$, pendidikan gizi. Lansia dengan penyakit degeneratif perlu diberikan konseling gizi . Konseling gizi misalnya posyandu lansia yang bertujuan untuk meningkatkan jangkauan pelayanan kesehatan di masyarakat. Pendidikan gizi yang bertujuan agar masyarakat dapat memiliki dan mempertahankan pola makan. Penyuluhan kesehatan dan konseling gizi bertujuan untuk mengembangkan pengertian yang benar dan sikap yang positif. (Waryana,2010).

\section{Rencana Kegiatan}

- Memohon ijin dari perangkat desa yang berkaitan dengan rencana kegiatan

- Mempersiapkan segala kebutuhan pengabdian kepada masyarakat

- Pelaksanaan yaitu penyuluhan kepada masyarakat sekaligus demonstrasi mengolah makanan yang baik dan benar

- Mengevaluasi pelaksanaan kegiatan 


\section{Pelaksanaan Kegiatan}

\section{Lokasi dan Waktu Pelaksanaan}

Lokasi Pengabdian Kepada Masyarakat ini yaitu di pulau Giliiyang Kecamatan Dungkek, yang dilaksanakan pada tanggal 3 Desember 2017.

\section{Kelompok Sasaran}

Sasaran dalam pengabdian kepada Masyarakat ini adalah lansia yang ada di pulau Giliiyang. Pada saat pelaksanaan pengabdiankepada masyarakat, masyarakat berpartisipasi aktif dan sangat antusias dengan materi yang kami berikan.Terbukti dengan ikut berpartisipasinya masyarakat saat persiapan pelaksanaan penyuluhan dan masyarakat juga terlibat langsung saat kami meminta partisipasi demonstrasi mengolah bahan makanan yang baik untuk lansia.

Rangkaian kegiatan yang dilakukan dalam kegiatan ini adalah:

a. Perencanaan.

$\begin{array}{lrr}\text { Perencanaan } & \text { dilakukan } & \text { untuk } \\ \text { menentukan } & \text { langkah- } & \text { langkah } \\ \text { pelaksanaan } & \text { program } & \text { dengan } \\ \text { mempersiapkan } & \text { instrument } & \text { yang } \\ \text { diperlukan selama pelaksanaan. } & \end{array}$

b. Kerjasama

Kegiatan PKM ini melibatkan beberapa mitra dalam upaya kerjasama menyukseskan pengabdian kepada masyarakat

c. Publikasi melalui media

Program dilaksanakan kemudian di publikasikan.

d. Pelaporan hasil akhir

Setelah kegiatan dilaksanakan maka selanjutnya membuat laporan akhir sebagai pertanggungjawaban secara administrative dari tim pelaksana kepada LPPM Universitas Wiraraja Sumenep.

\section{Pelaksanaan Kegiatan}

Lokasi dan Waktu Pelaksanaan: dilaksanakan di Pulau Gili Iyang Kecamatan Dungkek. Waktu pelaksanaannya adalah bulan 31 Desember 2017.

Kelompok Sasaran: Mitra dalam pelaksanaan kegiatan pengabdian kepada masyarakat ini adalah Kelompok lansia

Metode pelaksanaan kegiatan dalam pengabdian masyarakat dalam rangka menumbuhkan kesadaran masyarakat pulau Gili Iyang akan pentingnya penyuluhan menggunakan beberapa metode.

a. Sosialisasi dilakukan dengan memberikan penjelasan dan pengertian gizi seimbang lansia. Sosialisasi dilakukakan ditempattempat umum seperti di posyandu, masjid, dan rumah-rumah yang biasa menjadi tempat berkumpul ibu-ibu.

b. Komunikasi interaktif, dimana tim pengabdian kepada masyarakat membuka ruang komunikasi interaktif dengan mitra kerja. Selanjutnya menjadi fasilitator bagi masyarakat.

c. Langkah-langkah Kegiatan: Rangkaian kegiatan yang dilakukan untuk program pengabdian pada masyarakat sebagai berikut:

\section{1) Perencanaan}

Perencanaan dilakukan untuk menentukan langkah-langkah pelaksanaan program dengan mempersiapkan instrument yang diperlukan selama pelaksanaan pengabdian. Seperti menemukan mitra yang akan diajak untuk kerjasama dalam pengabdian dan diteruskan dengan mempersiapkan instrument atau alat yang dibutuhkan selama interkasi dengan masyarakat 


\section{2) Kerjasama}

Pengandian ini melibatkan beberapa mitra dalam upaya kerjasama mensukseskan pengadian kepada masyarakat

\section{3) Publikasi melalui media}

Program yang dilaksanakan, kemudian dipublikasikan

\section{4) Pelaporan Akhir}

Laporan akhir merupakan laporan dari seluruh rangkaian kegiatan sebagai wujud pertanggungjawaban secara administratif dari tim pelaksana kepada LPPM Universitas Wiraraja Sumenep. Kegiatan membutuhkan waktu selama enam bulan.

\section{Hasil Kegiatan Dan Pembahasan}

\section{Hasil Kegiatan}

a. Perangkat Desa khususnya kepala desa memberikan dukungan penuh dengan kegiatan yang kami berikan, terbukti dengan partisipasi dari perangkat desa dan kepala desa meminta kembali kepada kami untuk melakukan kegiatan yang sama.

b. Pengabdian kepada masyarakat dilaksanakan pada hari minggu tanggal 3 Desember 2017 pukul 09.00 WIB. Masyarakat sangat antusias dan berperan aktif terhadap kegiatan penyuluhan ini. Masyarakat ikut mendemonstrasikan cara pengolahan bahan makanan yang baik dan benar khususnya untuk lansia dan $70 \%$ masyarakat dapat menjelaskan kembali materi yang sudah diberikan.

c. Setelah dilakukan penyuluhan angka kejadian hipertensi dan lansia sakit beresiko berkurang di pulau Giliiyang d. Lansia dapat menentukan dan mengolah menu makanan seimbang bagi lansia

e. Posyandu Lansia di desa Giliiyang menjadi lebih aktif.

\section{Faktor Pendorong dan Penghambat}

a. Faktor Pendorong

- Angka lansia sakit beresiko yang meningkat beberapa bulan terakhir

- Timbulnya kesadaran dari tokoh masyarakat dan perangkat desa untuk mengatasi permasalahan

- Berperan aktif nya masyarakat untuk mengatasi permasalahan

b. Faktor Penghambat

- Tingkat pendidikan dan pengetahuan yang rendah pada masyarakat

- Letak demografi Desa Giliiyang yang jauh dari kecamatan

- Kurang aktifnya posyandu lansia

c. Upaya yang dilakukan untuk mengatasi hambatan

- Menggunakan media leaflet, poster menyampaikan beberapa informasi yang berkaitan dengan kesehatan dan menggunakan metode demonstrasi.

- Mempersiapkan sarana dan prasarana yang tepat untuk sampai di pulau Giliiyang dan melaksanakn kegiatan disaat cuaca baik.

- Memberikan pengarahan kepada kader posyandu lansia dan masukan kepada petugas kesehatan yang berwenang akan pentingnya posyandu lansia.

d. Catatan pembahasan

Kegiatan pengabdian kepada masyarakat di Pulau giliiyang Kecamatan Dungkek mendapat sambutan yang sangat baik dari masyarakat pulau Giliiyang. Adanya program kegiatan pengabdian kepada masyarakat ini diharapkan akan mampu meningkatkan kesadaran masyarakat pulau Giliiyang akan pentingnya nutrisi seimbang bagi lansia. Dengan pemberian sosialisasi dan pendampingan akan mampu 
meningkatkan pengetahuan masyarakat akan pentingnya nutrisi seimbang pada lansia.

\section{Penutup}

\section{a. Kesimpulan}

- Setelah dilakukan penyuluhan tentang nutrisi seimbang, pengetahuan lansia bertambah tentang nutrisi seimbang.

- Pola hidup para lansia berubah lebih baik khususnya pada nutrisi

- Kebutuhan nutrisi lansia bertambah

- Para Lansia dapat menentukan menu makanan seimbang

\section{b. Saran}

- Bagi Masyarakat Masyarakat hendaknya lebih aktif lagi mencari informasi tentang nutrisi seimbang khususnya bagi lansia, merubah pola hidup dan lebih aktif mengunjungi posyandu lansia

- Bagi pelaksana

Pelaksana harus lebih dalam lagi menggali informasi sehingga dapat ditemukan permasalahan lain di masyarakat Giliiyang yang berkaitan dengan kesehatan.

\section{Daftar Pustaka}

Depkes RI, (2009). Kategori Umur.

Pemkab sumenep, (2017).

https://www.sumenepkab.go.id/wisata/ baca/Alam/gili-iyang. Diakses tanggal 18 Agustus 2017

Waryana, (2010). Gizi reproduksi.Pustaka irama.Sewon, Bantul, Yogyakarta 
ISSN : 2621-9379 (Online)

Volume 2, Nomor 1, Maret 2019 
ISSN : 2621-9379 (Online)

Volume 2, Nomor 1, Maret 2019 